\title{
Māui Street
}

By Morgan Godfery. Bridget Williams Books, Wellington, 2018.

RRP: \$14.99 ISBN: 9781988545486

Reviewed by Joanne Waitoa

For better or worse, the emergence of social media has created platforms for a range of diverse voices often left out of mainstream media. In particular, Indigenous voices have found amplification through new media channels that allow Indigenous people to tell their own stories rather than being “othered" as a subject in someone else's. Morgan Godfery's Māui Street blog was a New Zealand example of this potential to subvert traditional political commentary. Beginning as a university student addressing a variety of Indigenous and other political issues, Godfery has carved a path over three electoral cycles (and counting) as an astute observer and analyst of political and social issues in New Zealand, the Pacific region and beyond. Outside of his blog he has written articles for online and hard copy newspapers and magazines; peerreviewed academic journals; and book chapters. He has also provided comment on radio and television. Māui Street is now the curation of published pieces from across sources such as The Guardian, E-tangata, Overland Literary Journal and The Spinoff in addition to the original blogsite.

Māui Street is divided into five sections: "Whakapapa"; "Tōrangapū Māori"; "Aotearoa-New Zealand"; "Te Moana-Nui-a-Kiwa"; and "Poroporoaki-Remembering." The collection begins with "Whakapapa": "I Saw the Mountain Erupt: A Kawerau Childhood," originally published in the Journal of Urgent Writing (2017). This whakapapa is whānau history, community history, and national history. Small town New Zealand in the 1980s. His parents searching for identity and finding each other. A story that is typical yet defies stereotypes. This essay illustrates the forces that shaped the author and provides insight into how the precocious child became one of the nation's youngest and most insightful political commentators. It also illustrates the author's ability to traverse personal topics with honesty and vulnerability, as does the similarly crafted and heartfelt remembering of his Koro in "That's How the Trees Feel." It is through these personal accounts that the author reveals the depth of his storytelling ability to a reader more familiar with his political and social comment.

The second section, "Tōrangapū Māori," begins with an excellent 2015 essay from Overland. "Settled Peacefully" eviscerates John Key's uneducated statement of how New Zealand was settled (or rather "unsettled" to borrow from Dr Moana Jackson). Connecting Te Arawa stories of ongoing injustice to experiences in Canada and Australia, the author illustrates the collective re-remembering of the settler states which historicise colonialism as a relic of the Empire. The collective amnesia of centre-right leaders of the time of Key, Abbott and Harper was not accidental and served a particular purpose: "for the state, denying history is about preserving power." However, their progressive counterparts in Trudeau and Ardern have shown to date they are the more polished side of the same coin. Although forthcoming in acknowledging the wrongdoings of the past, they nonetheless allow the ongoing assault on Indigenous land, women and children, showing little regard for stopping contemporary injustice.

This section includes comment on a range of topics, addressing Māori political issues: Māori wards (the ongoing struggle for Māori representation); Te Paparahi o Te Raki report (affirming the sovereignty of tangata whenua); rebuking assimilationist policy (as if the Hunn Report was published five not fifty years ago); Waitangi Day (when Māori push back against national mythologies); and Winston Peters" race talk (including the great quote "this is vintage Winston. 
Except the wine has turned to vinegar"). "The End of Neither Left nor Right but Māori" closes this section and deserves more than a brief description for two reasons: first, the subject, i.e. the exit of the Māori Party from Parliament; and second, its place as an illustration of the author's ability to cut through the rhetoric to find both clarity and nuance in a mediascape mesmerised by savvy and soundbites (he speaks further to the savvy commentator phenomenon in the third section). Published by The Spinoff, it's also an example of writing across diverse platforms. Whether you support the Māori Party or not, the party and its players have made a significant impact on politics in New Zealand. Tariana Turia's integrity to cross the floor over the Foreshore and Seabed Act in 2004 cannot be overstated. The resolve required to push through what must have been a lonely time before she was joined in parliament by five other Māori Party MPs also requires some consideration. Right or wrong, by giving confidence and supply to a National government, the Māori Party showed that Labour needed more than habit and religious prophecy to rely on Māori support. While it wasn't allocated the resources to achieve what Professor Sir Mason Durie first envisioned, Whannau Ora is a legacy that has the potential to be transformational. The Māori Party's actual legacy will remain to be seen and mulled over, as the party's shock exit was. Many reasons for their parliamentary demise were offered, including being tainted by National, Jacindamania, and "battered wives' syndrome." This article brings a perspective that "Neither Left nor Right but Māori" can't ignore. The majority of Māori voters didn't connect with the Māori Party, who "couldn't escape the divide between labour and capital, even if they were Māori." This intersectional lens is missing from many conversations about identity and Māori politics, and the author applies it regularly across his writing on these issues.

The third section, "Aotearoa-New Zealand," addresses national issues with similar nuance and begins with "For Queen and Country? No Thanks!" It is a discussion of republicanism and treaty relationships via the metaphor of a dusty photograph on a marae wall. Challenging British sovereignty of Aotearoa is not controversial in the left wing circles of this country; however, the critique in "On Opposition to Helen Clark (aka ImWithMarama, Your Progressive Fav is Problematic)" positions the author at odds with those who think the former prime minister should be supported in her bid for United Nations Secretary-General. This piece in the Overland demonstrates how weak a liberal position is without an Indigenous perspective. It tells hard truths about how progressives expect Māori to capitulate to national interest despite Helen Clark leading a Labour government that refused to ratify the United Nations Declaration for the Rights of Indigenous People; that enabled state sanctioned terror raids in Te Urewera; and that oversaw the greatest theft of Māori land in recent history. Those who challenge the concept of harmonious New Zealand on the world stage are traitors and the piece on Eleanor Catton's treason further highlights the immaturity of our national conversations at times. This section ends with one of the more insightful and honest entries of the collection, "Against Political Commentary," in which the author reflects on his own "game," labelling political commentary as bullshit and stating that commentators are not objective and have ulterior motives. He confesses to being a recovering savvy commentator and recognises the only real difference between political commentators and voters is the contrived authority of a media platform. How that platform is used is a key issue and can have negative impacts on public perception over time. Conversely, there are positive aspects and he notes that "political commentary is one way that ideas, including marginalised ideas from underrepresented groups, can enter the public sphere." I would suggest that the author and his works are a clear example of this but that our commentariat needs many more diverse views from the margins than it currently has. 
The fourth section, "Te Moana-Nui-a-Kiwa," continues the author's commentary to the sea of islands we also call the Pacific Ocean. Discerning media critique in pieces like "Disney's Moana isn't Progressive it's Dangerous" point out the tensions between representation and misrepresentation; cultural appropriation and cultural imperialism. This is in the context of the Pacific as "either a testing ground for anthropologists, a staging ground for US military operations, an easy setting for romantic escapism or a site for white projections." Similarly, writing for The Guardian, the author questions why Jonah from Tonga was quickly pulled from television following criticism in New Zealand, yet Chris Lilley's parodies are applauded and rewarded in his home country. The author illustrates the sad irony thus: "in Australia, the primary depiction of Polynesians in popular culture and the public sphere is a white bloke in brownface. Maybe this is the best satire of all but we are poorer for it." This section also contains two Overland entries on Tony Abbott's racial amendment act and the public and private actions and reactions to the tragedy of the refugee crises. The author's perceptive writing for The Guardian again, in "Orwell Would Recognise the Logic of Postcolonialism at Play in West Papua," illustrates that we need not look further than our own region for examples of ongoing colonialism and exploitation of Indigenous populations. The travesty occurring in West Papua needs amplification and it is heartening to see the author using the platform of an international newspaper to broadcast a present-day atrocity and to challenge governments to put human rights before trade and diplomacy in the Pacific.

The final section, "Poropoaki-Remembering," is a fitting farewell to an eclectic collection of writing. These touching pieces reflect on the lives and contributions to our lives of national identities. From the author's perspective we see these high-profile New Zealanders in more than two dimensions: Jonah Lomu was an international rugby star and political party campaigner; Parekura Horomia was a man of Labour and a man of faith; Dr Ranginui Walker supported a generation of Māori academics and activists, but was equally supported by his wife Dierdre. Not included was the author's farewell to his comrade Helen Kelly, written for The Spinoff in 2016. Regardless of the editorial decision that led to this omission it is available to read online. As previously mentioned, the collection ends with a personal recollection of whānau and childhood, in particular, Koro.

When I first started reading through the collection, I found it difficult to reconcile the inconsistency in style of the chapters from different sources. I was challenged further by not understanding the context of each piece-when it was written or where it was originally published - until the acknowledgements section at the end. On reflection, after revisiting the book with this knowledge, the difference in style is a strength rather than a weakness. This book provides an Indigenous perspective on significant political and social issues facing our country, our region and our world. I would consider it a useful introduction to any student of politics in Aotearoa. 